\title{
ANALISIS BERPIKIR LOGIS SISWA DALAM MENYELESAIKAN MATEMATIKA REALISTIK DITINJAU DARI KECERDASAN INTERPERSONAL
}

\author{
Asti Faradina', Mohammad Mukhlis ${ }^{2}$ \\ 1Program Studi Tadris Matematika Institut Agama Islam Negeri Jember \\ ${ }^{2}$ Institut Agama Islam Negeri Jember, Indonesia \\ astifaradina76@gmail.com
}

\begin{abstract}
This research was motivated by a variety of intelligence possessed by each individual. Where later intelligence was used to solve problems. The one intelligence that can be used in this study was interpersonal. This study aims to describe students' logical thinking in solving realistic mathematical problems in terms of interpersonal intelligence aspects of social sensitivity, social insight, and social communication, especially in mathematics subject matter in the Three Variable Linear Equation System (SPLTV). This research was descriptive. The subjects in this study were three students who had each of the aspects of interpersonal intelligence. Data collection in this study was a questionnaire or questionnaire, tests to solve realistic mathematical problems, interviews, observations, and documentation. Analysis of the data used was the model of Miles, Huberman, and Saldana through three stages including data condensation, data presentation, and conclusions. The validity of the data used triangulation techniques. The results obtained were students who had interpersonal intelligence aspects of social sensitivity meet one indicator of logical thinking and meet two indicators of problem-solving based on Polya's steps but still lacking. Students who had interpersonal intelligence aspects of social insight meet two indicators of logical thinking and can meet three indicators of problem-solving based on Polya's steps but still lacking. Students who had interpersonal intelligence aspects of social communication met all indicators of logical thinking while being able to meet all indicators of problem-solving.
\end{abstract}

Keywords: logical thinking, interpersonal intelligence, problem solving.

\section{PENDAHULUAN}

Pendidikan merupakan proses mengembangkan kecakapan individu dalam bermasyarakat. Pendidikan juga didefinisikan sebagai usaha sadar dan terencana yang dilakukan secara sistematis untuk mempersiapkan sekaligus mengembangkan potensi-potensi untuk menghadapi era globalisasi di masa yang akan datang. Hal ini sesuai dengan UU Nomor 20 tahun 2003 tentang Sistem Pendidikan Nasional pasal 3 (Kemendikbud, 2003) pendidikan mempunyai peran yang sangat penting dalam mempersiapkan segala sesuatu yang akan dihadapi di tahun-tahun berikutnya. Salah satu proses yang penting untuk dilakukan adalah kegiatan pembelajaran. Dalam hal ini maka dunia pendidikan harus mempersiapkan peserta didik yang memiliki kemampuan intelektual, emosional, sosial yang tinggi untuk mempersiapkan hal-hal yang terjadi akibat dari adanya perubahan yang terjadi di lingkungannya. Kemampuan merupakan salah satu aspek yang sangat penting untuk dimiliki oleh individu. Salah satu kemampuan yang sering kita lakukan dimanapun dan kapanpun sebelum melakukan sesuatu

Content from this work may be used under the terms of the Creative Commons AttributionShareAlike 4.0 International License that allows others to share the work with an acknowledgment of the work's authorship and initial publication in this journal. 
hal adalah kemampuan untuk berpikir. Berpikir merupakan kemampuan alamiah yang diberikan oleh Tuhan Yang Maha Esa yang sangat berharga. Berpikir merupakan suatu aktivitas pribadi manusia yang menghasilkan penemuan terarah dan kepada suatu tujuan. Kemampuan dalam berpikir seringkali dikaitkan dengan berpikir yang masuk akal atau biasa disebut berpikir logis atau logika.

Menurut Latif (2016) logika merupakan pengetahuan yang mempelajari kecakapan untuk berpikir secara tepat, lurus dan teratur. Dengan kata lain bahwa logis atau logika dikaitkan dengan pola pikir dalam menarik suatu kesimpulan sehingga menemukan jawaban secara masuk akal (logis). Dengan berpikir logis, seseorang mampu membedakan dan mengkritisi peristiwa yang sedang dialami, apakah peristiwa tersebut masuk akal dan sesuai dengan ilmu pengetahuan atau malah sebaliknya. Menurut Gardner (Mukhlis \& Tohir, 2019) kecerdasan yang dimilki oleh siswa yaitu: kecerdasan logis-matematis, visual-spasial, kinestetis, linguistic, interpersonal dan intrapersonal. Kemampuan berpikir logis melatih siswa untuk menyelesaikan masalah. Berikut akan disajikan indikator dari berpikir logis.

Tabel 1. Indikator Berpikir Logis

\begin{tabular}{|c|c|c|c|}
\hline No. & $\begin{array}{c}\text { Indikator } \\
\text { Berpikir Logis }\end{array}$ & Indikator & Keterangan \\
\hline 1. & $\begin{array}{l}\text { Keruntutan } \\
\text { Berpikir }\end{array}$ & $\begin{array}{l}\text { Siswa dapat } \\
\text { menyebutkan seluruh } \\
\text { informasi yang } \\
\text { didapatkan pada soal } \\
\text { (diketahui dan } \\
\text { ditanyakan). } \\
\text { Mengungkapkan } \\
\text { secara umum semua } \\
\text { langkah yang akan } \\
\text { digunakan untuk } \\
\text { penyelesaian masalah. }\end{array}$ & $\begin{array}{l}\text { Informasi yang bisa } \\
\text { didapatkan (diketahui) } \\
\text { didalam soal seperti harga } 1 \\
\text { kg kedelai jenis A, } 2 \text { kg jenis B } \\
\text { dan } 3 \text { kg jenis C dijual dengan } \\
\text { harga Rp. 15.600,00. } \\
\text { Sedangkan informasi yang } \\
\text { bisa didapatkan (ditanyakan) } \\
\text { didalam soal seperti harga } \\
\text { kedelai jenis manakah yang } \\
\text { paling mahal?. Kemudian } \\
\text { langkah yang digunakan } \\
\text { dalam menyelesaikan masalah } \\
\text { adalah memahami isi soal, } \\
\text { membuat pemodelan } \\
\text { mateamatika, menggunakan } \\
\text { metode yang sudah ada dan } \\
\text { menemukan jawaban yang } \\
\text { diinginkan. }\end{array}$ \\
\hline 2. & $\begin{array}{l}\text { Kemampuan } \\
\text { Berargumen }\end{array}$ & $\begin{array}{l}\text { Siswa dapat } \\
\text { mengungkapkan } \\
\text { alasan logis mengenai } \\
\text { seluruh langkah- } \\
\text { langkah penyelesaian } \\
\text { yang akan digunakan }\end{array}$ & $\begin{array}{l}\text { Dimulai informasi diketahui } \\
\text { dan ditanyakan yang } \\
\text { diperoleh. Selanjutnya, Jika } \\
\text { dalam campuran kedelai } \\
\text { pertama } 1 \text { kg kedelai jenis A, } \\
2 \text { kg jenis B dan } 3 \text { kg jenis C }\end{array}$ \\
\hline
\end{tabular}




\begin{tabular}{|c|c|c|c|}
\hline No. & $\begin{array}{c}\text { Indikator } \\
\text { Berpikir Logis }\end{array}$ & Indikator & Keterangan \\
\hline 3. & $\begin{array}{l}\text { Penarikan } \\
\text { Kesimpulan }\end{array}$ & $\begin{array}{l}\text { dari awal hingga } \\
\text { mendapat kesimpulan } \\
\text { dengan benar. } \\
\text { Menyelesaikan soal } \\
\text { secara tepat pada } \\
\text { setiap langkah serta } \\
\text { dapat memberikan } \\
\text { argumen pada setiap } \\
\text { langkah-langkah yang } \\
\text { digunakan dalam } \\
\text { pemecahan masalah. } \\
\text { Mengungkapkan } \\
\text { alasan yang logis untuk } \\
\text { jawaban akhir yang } \\
\text { kurang tepat. }\end{array}$ & $\begin{array}{l}\text { dijual dengan harga Rp. } \\
\text { 15.600,00. Kemudian } \\
\text { campuran kedelai kedua } \\
\text { terdiri dari } 2 \text { kg jenis A, dan } 3 \\
\text { kg jenis B dengan hara Rp } \\
\text { 12.000,00. Sedangkan } \\
\text { campuran kedelai ketiga } \\
\text { terdiri dari } 1 \text { kg jenis A dan } 1 \\
\text { kg jenis C dengan harga Rp } \\
\text { 5.400,00. Lalu harga kedelai } \\
\text { yang paling mahal adalah? } \\
\text { menyelesaikan suatu masalah } \\
\text { tersebut dapat menggunakan } \\
\text { metode yang sudah ada untuk } \\
\text { mempermudah penyelesaian } \\
\text { seperti menggunakan metode } \\
\text { substitusi, eliminasi, } \\
\text { gabungan dan determinan. } \\
\text { Setelah melewati langkah- } \\
\text { langkah penyelesaian } \\
\text { masalah, pada langkah akhir } \\
\text { siswa mendapatkan jawaban } \\
\text { yang diinginkan seperti harga } \\
\text { jenis kedelai yang paling } \\
\text { mahal adalah jenis kedelai C. }\end{array}$ \\
\hline
\end{tabular}

Sumber: Andriawan (2014)

Aktivitas berpikir tidak akan lepas dari suatu masalah untuk dipecahkan khususnya masalah matematika. Carl Friedrich Gauss (Erviana, 2019) mengatakan bahwa matematika adalah ratunya ilmu pengetahuan. Sedangkan definisi masalah matematika menurut Saad \& Ghani (Cahyani \& Setyawati, 2017) sebagai situasi yang memiliki tujuan yang jelas tapi berhadapan dengan halangan akibat kurangnya algoritma yang diketahui untuk menguraikannya agar memperoleh sebuah solusi. Suatu masalah tidak akan memberikan kesimpulan jika tidak ada suatu penyelesaian masalah. Menurut Gartmam \& Freiberg (Munawwarah, Laili, \& Tohir, 2020) dalam proses pemecahan masalah terdapat proses menyadari dan mengatur berpikir tentang siswa untuk melakukan pendekatan dari suatu masalah, siswa dapat memilih strategi dalam menyelesaikan permasalahan dan bertanya kepada diri sendiri tentang masalah tersebut. Selain itu, (Tohir, Maswar, Atikurrahman, Saiful, \& Pradita, 2020) mengatakan bahwa peran guru sangatlah penting dalam pembelajaran matematika sekolah, agar proses berpikir matematis siswa harus selalu tetap diasah setiap saat secara kontinu dan berkesinambungan, agar berpikir matematis siswa lebih sempurna. Pada pembelajaran matematika

Alifmatika: Jurnal Pendidikan dan Pembelajaran Matematika, Desember 2020, Vol. 2, No. 2 
seringkali ditemui siswa yang mengalami kebingungan atau permasalahan yang dikaitkan dengan masalah yang dekat dengan kehidupan sehari-hari atau yang disebut dengan masalah matematika realistik salah satunya pada materi SPLTV. Menurut Sarbiyono (Tohir, 2017) mengintegrasikan konsep ke dalam konteks kehidupan sehari-hari atau realistik dapat menjadi alat yang efektif untuk mengembangkan berbagai disiplin ilmu. Dalam hal ini perlu kiranya memanfaatkan kecerdasan yang dimiliki oleh masing-masing individu meliputi kecakapan, ketanggapan yang harus diterapkan, khususnya cakap dan tanggap dalam hal berkomunikasi atau meningkatkan hubungan sosial dengan orang lain. Kecerdasan yang dimaksud adalah kecerdasan interpersonal.

Kecerdasan interpersonal memiliki peranan yang sangat penting bagi seseorang ataupun siswa untuk menyelesaikan suatu masalah kehidupan maupun masalah yang ada di sekolah. Gardner (Sholeh, 2016) menyebutkan bahwa kecerdasan Interpersonal adalah kemampuan untuk memahami dan bekerja sama. Selain itu, Safaria (Aprilia, 2013) memaparkan bahwa kecerdasan interpersonal adalah kemampuan dan keterampilan seseorang dalam menciptakan hubungan, membangun dan mempertahankan hubungan sosialnya. Kecerdasan interpersonal mempunyai pengaruh yang besar kepada siswa dalam menyelesaikan suatu masalah, misalnya ketika mengalami kebingungan, siswa tidak akan malu bertanya kepada teman atau guru yang ada di sekelilingnya atau bahkan yang baru ia kenal. Maka dari itu kecerdasan interpersonal perlu untuk ditingkatkan didalam sekolah maupun dalam masyarakat.

Safaria menambahkan bahwa ada tiga aspek dari kecerdasan interpersonal, diantaranya adalah Social sensitivity, Social insight dan Social communication. Social sensitivity atau sensitivitas sosial, yaitu kemampuan individu untuk merasakan dan mengamati reaksi atau perubahan orang lain yang ditunjukkannya baik secara verbal maupun non-verbal. Social insight, yaitu kemampuan seseorang untuk memahami dan mencari pemecahan masalah secara efektif dalam suatu interaksi sosial, sehingga masalah-masalah yang nantinya terjadi tidak akan merusak relasi sosial yang telah dibangun sesorang tersebut. Sedangkan Social communication atau penguasaan keterampilan komunikasi sosial merupakan kemampuan seseorang untuk menggunakan proses komunikasi dalam membangun sebuah hubungan interpersonal dengan orang lain.

Hasil penelitian dari Andriawan (2014) menunjukkan bahwa subjek berkemampuan pemecahan masalah tinggi menunjukkan dalam setiap langkahnya memberikan kesimpulan dengan tepat. Sedangkan subjek berkemampuan pemecahan masalah sedang menunjukkan dalam setiap langkahnya memberikan kesimpulan kurang tepat. Sedangkan subjek berkemampuan pemecahan masalah rendah menunjukkan dalam setiap langkahnya tidak mampu memberikan argumen dan kesimpulan.

Berdasarkan uraian diatas, maka perlu diadakan penelitian yang berbeda dari sebelumnya. Penelitian sebelumnya melakukan penelitian menggunakan subjek yang memiliki kemampuan tinggi, sedang dan rendah. Sedangkan penelitian ini dilakukan menggunakan subjek yang memiliki kecerdasan interpersonal dengan berbagai aspek yakni aspek social sensitivity, social insight dan social communication dalam menyelesaikan suatu masalah matematika realistik materi SPLTV. Oleh karena itu, maka tujuan dari penelitian ini adalan ingin

Alifmatika: Jurnal Pendidikan dan Pembelajaran Matematika, Desember 2020, Vol. 2, No. 2 
mendeskripsikan kemampuan berpikir logis siswa yang memiliki kecerdasan interpersonal aspek social sensitivity, social insight dan social communication dalam menyelesaikan suatu masalah matematika realistik materi SPLTV.

\section{METODE PENELITIAN}

Penelitian ini menggunakan pendekatan kualitatif dengan metode deskriptif. Lokasi yang dipilih untuk dijadikan penelitian ini bertempat di SMA Negeri Jenggawah yang terletak di Jl. Tempurejo Wetan Gunung No. 76 Desa Wonojati Kecamatan Jenggawah Kabupaten Jember. Langkah awal yang dilakukan adalah penentuan subjek. Pemilihan subjek memanfaatkan pembagian angket kecerdasan interpersonal dengan teknik purposive yaitu penentuan sumber data yang diwawancarai yang dipilih menurut pertimbangan dan tujuan tertentu. Dari kelas X IPA 1 yang diberikan angket, diperoleh tiga siswa yang mendapatkan skor tertinggi dan dijadikan subjek untuk penelitian.Berikut merupakan daftar subjek penelitian.

Tabel 2. Daftar Subjek Penelitian Berdasarkan Aspek Kecerdasan Interpersonal

\begin{tabular}{ccccc}
\hline \multirow{2}{*}{ No. } & Aspek Kecerdasan & Skor & RM \\
\hline 1. & Interpersonal & SP & AP & 41 \\
2. & Social Sensitivity & 46 & 40 & 65 \\
3. & Social Insight & 60 & 66 & 43 \\
\hline
\end{tabular}

Dari tabel diatas didapatkan data yang menunjukkan subjek yang memiliki aspek kecerdasan interpersonal adalah yang paling tinggi nilainya. Diketahui pada baris 1 (social sensitivity) bahwa subjek SP mendapatkan nilai tertinggi diantara yang lain yakni 46, hal tersebut menunjukkan bahwa subjek SP yang memiliki kecerdasan interpersonal aspek social sensitivity. Pada baris 2 (social insight) subjek AP mendapatkan nilai tertinggi diantara yang lain yakni 66, hal tersebut menunjukkan bahwa subjek AP yang memiliki kecerdasan interpersonal aspek social insight. Sedangkan pada baris 3 (social communication) subjek RM mendapatkan nilai tertinggi diantara yang lain yakni 40, hal tersebut menunjukkan bahwa subjek RM yang memiliki kecerdasan interpersonal aspek social communication.

Teknik pengumpulan data merupakan hal terpenting dalam penelitian, karena tujuan utama dari sebuah penelitan adalah untuk mendapatkan data. Teknik pengumpulan data pada penelitian ini adalah kuesioner atau angket, tes, wawancara, observasi dan dokumentasi. Setelah data terkumpul, maka akan dilakukan tahap selanjutnya, yakni langkah analisis data. Teknik analisis data yang digunakan dalam penelitian ini menggunakan model analisis Huberman, Miles, \& Saldana (2014) dengan tiga tahap: kondensasi data, penyajian data dan penarikan kesimpulan. Penarikan kesimpulan dilakukan dengan menggunakan triangulasi teknik (Tohir, Susanto, Hobri, Suharto, \& Dafik, 2018).

\section{HASIL PENELITIAN DAN PEMBAHASAN}

Tes kemampuan berpikir logis siswa dalam menyelesaikan masalah matematika realistik pada materi SPLTV diberikan kepada subjek yang telah terpilih untuk

Alifmatika: Jurnal Pendidikan dan Pembelajaran Matematika, Desember 2020, Vol. 2, No. 2 
kemudian diselesaikan. Dibawah ini adalah tabel keterkaitan indikator berpikir logis dan penyelesaian masalah.

Tabel 3. Keterkaitan Indikator Berpikir Logis dengan Indikator Penyelesaian Masalah

\begin{tabular}{ccc}
\hline No. & Indikator Berpikir Logis & Indikator Penyelesaian Masalah \\
\hline 1. & Keruntutan Berpikir & Memahami Masalah \\
& Merencanakan Penyelesaian \\
2. & Kemampuan Berargumen & Melakukan Pengecekan Kembali \\
3. & Penarikan Kesimpulan & Masalah \\
\hline
\end{tabular}

Hasil yang didapatkan pada penelitian adalah siswa yang memiliki kecerdasan interpersonal aspek social sensitivity memenuhi satu indikator berpikir logis dan memenuhi dua indikator penyelesaian masalah berdasarkan langkah Polya namun masih kurang. Siswa yang memiliki kecerdasan interpersonal aspek social insight memenuhi dua indikator berpikir logis dan dapat memenuhi tiga indikator penyelesaian masalah berdasarkan langkah Polya namun masih kurang. Sedangkan siswa yang memiliki kecerdasan interpersonal aspek social communication memenuhi semua indikator berpikir logis sekaligus dapat memenuhi semua indikator penyelesaian masalah.

Berikut ini adalah deskrispi kemampuan berpikir logis siswa dalam menyelesaikan masalah matematika realistik materi SPLTV.

Soal 1: Seorang penjual kedelai mencampur tiga jenis kedelai. Campuran kedelai pertama terdiri atas $1 \mathrm{~kg}$ jenis A, $2 \mathrm{~kg}$ jenis B, dan $3 \mathrm{~kg}$ jenis $C$ dijual dengan harga $R p$. 15.600,00. Campuran kedelai kedua terdiri dari $2 \mathrm{~kg}$ jenis A dan $3 \mathrm{~kg}$ jenis $B$ dijual dengan harga Rp. 12.000,00. Campuran kedelai ketiga terdiri dari $1 \mathrm{~kg}$ jenis A dan $1 \mathrm{~kg}$ jenis $C$ dijual dengan harga $R$. 5.400,00. Harga kedelai jenis manakah yang paling mahal?

Soal 2: Diketahui Dira berumur 6 tahun lebih tua dari Erik. Sedangkan umur Erik 2 tahun lebih tua dari Fira. Jika jumlah umur Dira, Erik dan Fira adalah 85 tahun, maka jumlah umur Dira dan Erik adalah?

\section{Kemampuan Berpikir Logis Siswa pada Subjek SS yang Memiliki Kecerdasan Interpersonal Aspek Social Sensitivity dalam Menyelesaikan Masalah Matematika Realistik Materi SPLTV}

Siswa SS merupakan siswa yang erat kaitannya dengan kemampuan individu meliputi sikap empati dan prososial.

1) Keruntutan Berpikir

Indikator berpikir logis keruntutan berpikir meliputi tahapan memahami masalah dan merencanakan penyelesaian. Berikut hasil analisis siswa SS dari beberapa teknik pada soal nomor satu.

a) Teknik Tes

Alifmatika: Jurnal Pendidikan dan Pembelajaran Matematika, Desember 2020, Vol. 2, No. 2 
Berikut adalah hasil penyelesaian siswa SS yang memiliki kecerdasan interpersonal aspek social sensitivity.

$$
\text { 1.) } \begin{aligned}
A+2 B+3 C & : 15.600 \ldots(1) \\
2 A+3 B & : 12.000 \ldots(2) \\
2 A+2 C & =5.400 \ldots(3)
\end{aligned}
$$

\section{Gambar 1. Jawaban SS Soal Nomor Satu Keruntutan Berpikir}

Berdasarkan hasil penyelesaian siswa SS pada soal nomor satu, siswa yang memiliki kecerdasan interpersonal aspek social sensitivity pada tahap memahami masalah, siswa SS dapat memahami informasi sehingga dia membuat sebuah pemodelan sebelum masuk ke tahap selanjutnya. Hal ini menunjukkan pada tahap merencanakan penyelesaian berhasil dilalui, dimana dia merancang pemodelan terlebih dahulu.

b) Teknik Wawancara

Berikut adalah potongan hasil wawancara yang menunjukkan pada tahap menyelesaikan masalah.

P02 : Kamu tau nggak yang dari soal diatas yang diketahui itu apa, yang ditanyakan itu apa ngerti nggak?

SS02 : Harga jenis kedelai manakah yang lebih mahal

P03 : apa aja yang diketahui? coba jelaskan

SS04 : Ini bu (sambil menunjuk jawaban di kertas), $a+2 b+3 c$

Pada potongan hasil wawancara diatas diketahui bahwa siswa SS dapat memahami apa yang ditanyakan pada soal yakni harga jenis campuran kedelai manakah yang lebih mahal. Namun untuk yang diketahui siswa SS tidak dapat menjelaskan secara rinci apa yang diketahui dalam soal. Dengan hanya menunjuk pada lembar jawaban.

\section{c) Teknik Observasi}

Pada pengamatan yang dilakukan oleh peneliti, peneliti melihat siswa SS merasa kebingungan saat mengerjakan soal yang diberikan. Siswa SS melihat kesana kemari untuk meminta bantuan kepada temannya.

Sehingga dapat diketahui bahwa siswa SS dapat memenuhi tahapan memahami masalah dalam indikator penyelesaian masalah berdasarkan langkah Polya (Polya, 1973). Kemudian pada tahap merencanakan masalah siswa SS berhasil untuk mengerjakannya namun masih ada pemodelan yang kurang tepat. Jadi dapat disimpulkan siswa SS pada indikator berpikir logis pada tahapan memahami masalah dan merencanakan masalah keruntutan berpikir bisa terpenuhi namun masih kurang. Hal ini terjadi dikarenakan kemampuan berpikir siswa kurang dikarenaka proses berpikirnya dalam memahami soal dengan menggunakan strategi mencoba-coba dan dalam proses

Alifmatika: Jurnal Pendidikan dan Pembelajaran Matematika, Desember 2020, Vol. 2, No. 2 
penyelesaiannya kurang teliti dan kurang cermat, karena ada satu langkah yang lupa tidak ditulis (Tohir, Susanto, et al., 2018).

2) Kemampuan Berargumen

Indikator keruntutan berpikir meliputi tahapan menyelesaikan masalah.

a) Teknik Tes

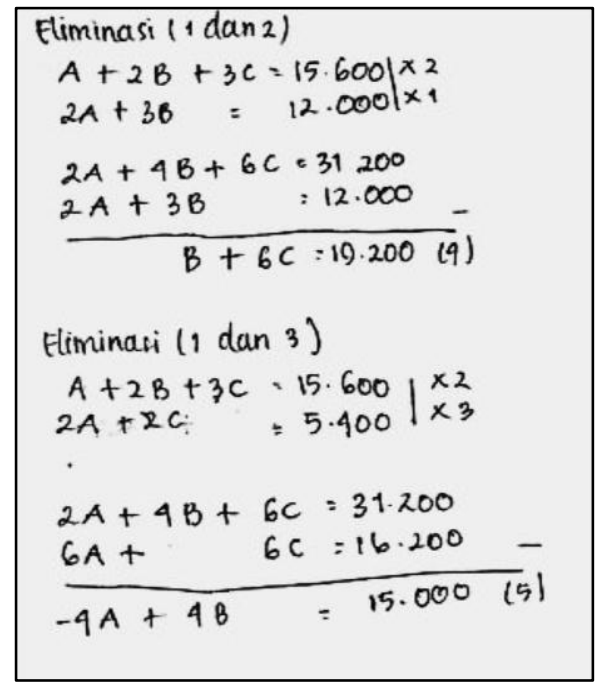

Gambar 2. Jawaban SS Soal Nomor Satu Kemampuan Berargumen

Dari hasil penyelesaian diatas, terlihat siswa SS dalam menyelesaikan masalah hanya mengerjakan setengah perjalanan. Dimana dia merencanakan melakukan penyelesaian menggunakan metode gabungan (substitusi dan eliminasi) namun tidak berhasil menuntaskannya.

b) Teknik Wawancara

Berikut adalah potongan hasil wawancara yang dilakukan.

P05 : Setelah dapat soal, bayangan kamu cara mengerjakan itu gimana?

SS05 : Bismillah pokok bu, nggak tau saya bu

P06 : Langkah-langkahnya mengerjakan gimana?

SS06 : Ya ini dah bu (menunjuk di kertas jawaban), nyari eliminasi 1 dan 2 lalu mencari eliminasi 1 dan 3

P07 : Lalu?

SS07 : Saya nggak tau, Bu

Diketahui dari hasil wawancara diatas siswa SS tidak bisa dalam menyelesaikan masalah yang diberikan. Hanya menyebutkan "Ya ini dah bu (menunjuk di kertas jawaban), nyari eliminasi 1 dan 2 lalu mencari eliminasi 1 dan 3" tanpa menyebutkan langkah seelanjutnya yang harus dilewati sampai akhirnya masalah tersebut menemukan suatu penyelesaian.

c) Teknik Observasi

Pada teknik ini terlihat bahwa siswa SS kebingungan dalam mengerjakan soal yang diberikan. Dia berusaha bertanya kepada temannya bagaimana cara atau langkah

Alifmatika: Jurnal Pendidikan dan Pembelajaran Matematika, Desember 2020, Vol. 2, No. 2 
yang harus dilakukan untuk menemukan jawaban yang diinginkan. Selain itu, siswa SS melihat kesana kemari (tolah toleh) ke lembar jawaban temannya yang lain.

Berdasarkan pernyataan diatas dapat diketahui bahwa siswa SS belum bisa memenuhi tahapan kemampuan berargumen pada indikator logis, sekaligus tidak dapat memenuhi indikator penyelesaian masalah berdasarkan langkah Polya pada tahap menyelesaikan masalah. Hal ini terjadi dikarenakan siswa kemahiran dalam menyelesaikan masalah berdasarkan ide-ide yang pernah ia dapatkan sebelumnya (Tohir, Susanto, et al., 2018).

3) Penarikan Kesimpulan

a) Teknik Tes

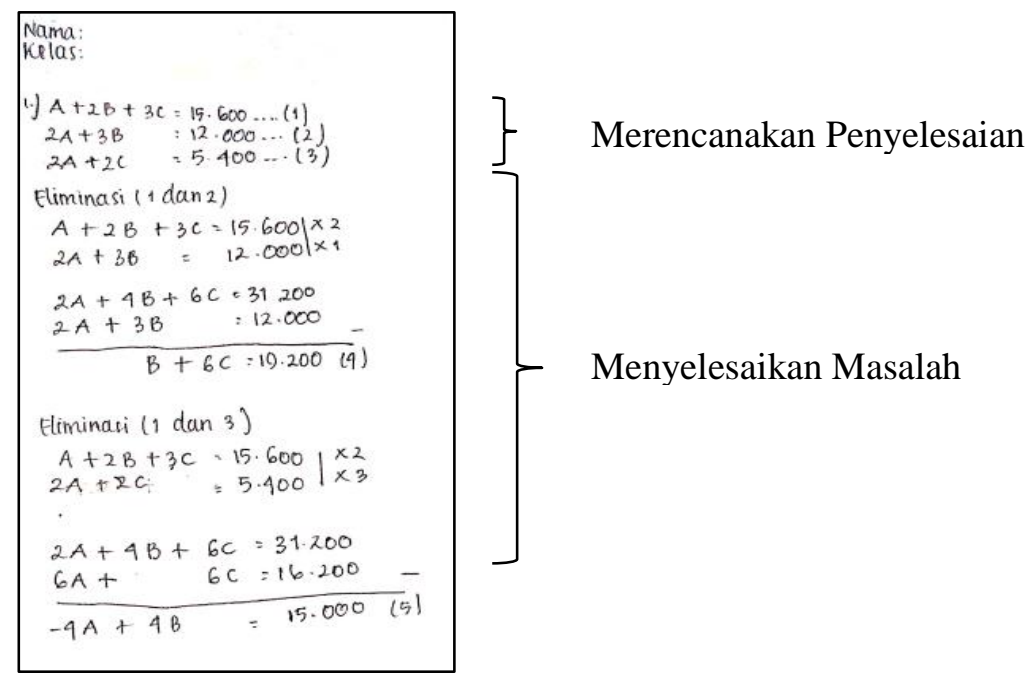

Gambar 3. Jawaban SS Soal Nomor Satu Penarikan Kesimpulan

Dari hasil tes pada lembar jawaban diketahui siswa SS tidak menuliskan kesimpulan maupun melakukan pengecekan kembali untuk meyakinkan apakah jawaban yang diperoleh jika dimasukkan ke salah satu persamaan sesuai dengan hasil dari persamaan tersebut atau tidak. Karena dia tidak menyelesaikan langkah di tahap menyelesaikan masalah sampai selesai dan menemukan jawabannya, maka dia tidak dapat melakukan tahapan terakhir yakni melakukan pengecekan.

b) Teknik Wawancara

Pada teknik ini peneliti tidak menanyakan apakah dia melakukan pengecekan kembali atau tidak, karena sudah dapat dilihat dalam hasil lembar jawaban bahwa dia tidak dapat menuntaskan atau menyelesaikan secara lengkap bagaimana samai dia mendapatkan hasil yang diharapkan.

c) Teknik Observasi

Dari hasil pengamatan yang didapatkan, siswa SS terlihat kebingungan dalam menemukan penyelesaian yang diharapkan. Sehingga tidak dituntaskan sekaligus tidak melakukan pengecekan kembali. Pada pernyataan diatas menunjukkan bahwa siswa SS tidak dapat memenuhi indikator dari berpikir logis yaitu melakukan penarikan kesimpulan dan juga tidak dapat melakukan pengecekan kembali pada indikator penyelesaian masalah berdasarkan langkah Polya.

Alifmatika: Jurnal Pendidikan dan Pembelajaran Matematika, Desember 2020, Vol. 2, No. 2 


\section{Kemampuan Berpikir Logis Siswa pada Subjek SI yang Memiliki Kecerdasan Interpersonal Aspek Social Insight dalam Menyelesaikan Masalah Matematika Realistik Materi SPLTV}

Siswa yang memiliki kecerdasan interpersonal social insight adalah siswa yang erat kaitannya dengan kemampuan individu yang meliputi berkembangnya kesadaran diri, pemahaman situasi sosial serta etika sosial dan pemecahan masalah efektif. Berikut adalah hasil penyelesaian siswa SI yang memiliki kecerdasan interpersonal social insight.

1) Keruntutan Berpikir

Indikator berpikir logis keruntutan berpikir meliputi tahapan memahami masalah dan merencanakan penyelesaian. Berikut hasil analisis siswa SI dari beberapa teknik pada soal nomor satu.

a) Teknik Tes

Berikut adalah hasil penyelesaian masalah dari siswa SI.

$$
\begin{aligned}
& \text { 1. Misal: Jenis } A: a \text {, Jenic } B: b \text {, Jenis } c: c \\
& a+2 b+3 c=16.600 \ldots \ldots, 0 \\
& 2 a+3 b=12.000 \ldots \ldots \text {. } \\
& a+c=5.400 \ldots \ldots \text {. }
\end{aligned}
$$

Gambar 4. Jawaban SI Soal Nomor Satu (kiri) dan Soal Nomor Dua (kanan)

Dari hasil penyelesaian siswa SI pada soal nomor satu, dapat diketahui bahwa siswa memahami informasi yang ada didalam soal dengan membuat pemisalan jenis campuran kedelai A $(\mathrm{kg})$ dengan a, jenis campuran kedelai $\mathrm{B}(\mathrm{kg})$ dengan b dan jenis campuran kedelai C (kg) dengan c. Didalam soal memaparkan bahwa diketahui $1 \mathrm{~kg}$ jenis A, $2 \mathrm{~kg}$ jenis B dan $3 \mathrm{~kg}$ jenis C dijual dengan harga Rp. 15.600,00. Siswa SI membuat pemodelan $\mathrm{a}+2 \mathrm{~b}+3 \mathrm{c}=15.600$ (persamaan 1). Campuran kedelai kedua terdiri dari $2 \mathrm{~kg}$ jenis A dan $3 \mathrm{~kg}$ jenis B dijual dengan harga Rp. 12.000,00 untuk pemodelan matematika siswa SI menuliskan $2 a+3 b=12.000$ (persamaan 2). Untuk campuran kedelai ketiga diketahui terdiri dari $1 \mathrm{~kg}$ jenis $\mathrm{A}$ dan $1 \mathrm{~kg}$ jenis $\mathrm{C}$ dijual dengan harga Rp. 5.400,00 dengan pemodelan $\mathrm{a}+\mathrm{c}=5.400$.

\section{b) Teknik Wawancara}

Berikut hasil wawancara dari siswa SI.

P02 : Kalau sudah paham, informasi apa yang kamu dapat dari soal nan?

SI02 : Saya dapat mengetahui harga jenis kedelai manakah yang paling mahal, itu yang nomor 1. Kalau yang nomor 2 jumlah umur Dira sama Erik

Dari hasil wawancara yang dilakukan didapatkan bahwa siswa SI memahami informasi didalam soal. Menyebutkan bahwa yang ditanyakan didalam soal nomor satu adalah harga jenis campuran kedelai manakah yang lebih mahal.

Alifmatika: Jurnal Pendidikan dan Pembelajaran Matematika, Desember 2020, Vol. 2, No. 2 
c) Teknik Observasi

Pada teknik ini, peneliti mencatat secara langsung apa yang dilihat, didengar dan dirasakan. Pada teknik observasi atau pengamatan peneliti melihat bahwa siswa SI terlihat sangat paham dengan informasi apa yang didapatkan dari soal, dia menyebutkan apa yang ditanyakan dan diketahui dalam soal yang diberikan.

Siswa SI dapat memenuhi tahapan memahami masalah dalam indikator penyelesaian masalah berdasarkan langkah Polya. Kemudian pada tahap merencanakan masalah siswa SI berhasil untuk mengerjakannya. Jadi dapat disimpulkan bahwa siswa SI pada indikator berpikir logis tahapan memahami masalah dan merencanakan masalah dapat melewatinya. hasil penelitian ini sejalan dengan hasil penelitian yang didapt oleh Tohir (2017) menunjukkan bahwa siswa dengan kemampuan tinggi pada tahapmengidentifikasi masalah yang ditanyakan dengan baik, siswa memilih informasi yang dibutuhkan dan informasi yang tidak dibutuhkan dalam penyelesaian masalah dengan tepat.

1) Kemampuan Berargumen

Indikator berpikir logis keruntutan berpikir meliputi tahapan menyelesaikan masalah.

a) Teknik Tes

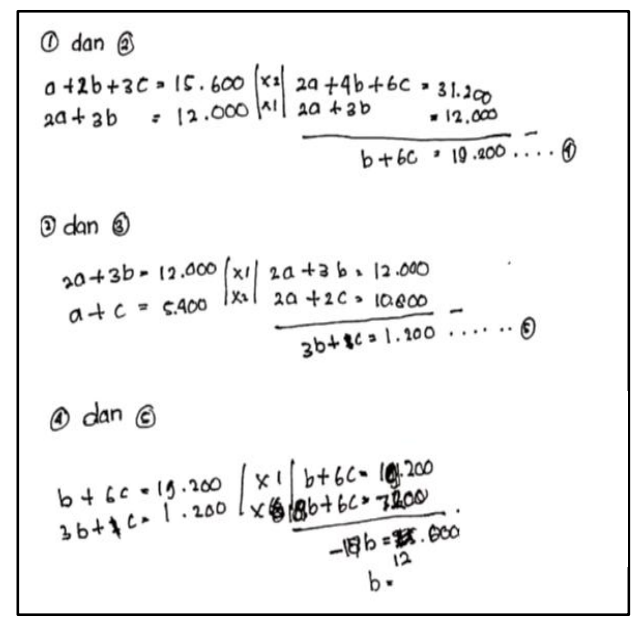

Gambar 5. Jawaban SI pada Soal Nomor Satu

Dari paparan hasil jawaban yang telah dikerjakan, diketahui bahwa siswa SI menggunakan metode gabungan (eliminasi dan substitusi) dalam menyelesaikan masalah yang diberikan. Dimana dia menggunakan persamaan satu dan persamaan dua untuk dieliminasi dan mendapatkan persamaan baru yakni persmaan empat, kemudian dia melanjutkan lagi dengan mengeliminasi persamaan dua dan persamaan tiga menghasilkan persamaan lima, setelah itu terlihat siswa SI mencorat coret lembar jawaban yang menunjukkan langkah selanjutnya.

b) Teknik Wawancara

Berikut hasil wawancara yang diperoleh dari siswa SI.

P04 : Waktu kamu mengerjakan, langkah-langkahnya gimana nan?

SI04 : Pertama saya melakukan pemisalan, kedelai pertama jenis A, B, C. Saya misalkan jenis A itu $x$, B itu $y$ dan $\mathrm{C}$ itu $z$, dan harganya itu dimasukan seperti biasanya. Setelah itu saya memasukan persamaan. Pertama kan diketahui

Alifmatika: Jurnal Pendidikan dan Pembelajaran Matematika, Desember 2020, Vol. 2, No. 2 
persamaan 1, 2 dan 3. Persamaan 1 dan 2 dieliminasi dijadikan persamaan 4. Kemudian persamaan 2 dan 3 dilakukan eliminasi hasilnya jadi persamaan 5 . Kemudian persamaan 4 dan 5 saya melakukan eliminasi dan diketahui nilai c nya. Setelah menemukan nilai c saya memasukan pada persamaan yang lain sehingga dapat nilai b. Setelah itu, nilai $\mathrm{c}$ dan $\mathrm{b}$ dimasukan ke persamaan yang lain sehingga mendapatkan nilai a. Dari situ bisa didapatkan jawabanya harga nilai kedelai yang paling mahal.

Hasil wawancara tersebut memperkuat data bahwa sebenarnya siswa SI paham sekali cara atau langkah apa yang seharusnya digunakan dan dilakukan menggunakan metode yang paling umum dan mudah digunakan yaitu metode campuran (eliminasi dan substitusi). Namun pada saat mengerjakan, siswa SI mengakui bahwa dia salah dalam melakukan pemisalan.

SI03 : Kalau menurut saya, yang nomor 1 ini saya salah pemisalan saja. Kalau nomor 2 belum saya kerjakan.

c) Teknik Observasi

Pada teknik observasi atau pengamatan, peneliti melihat ketika siswa SI mengerjakan terlihat sangat yakin untuk proses awal, namun ketika sudah sampai di pertengahan, siswa SI telihat kebingungan untuk meneruskan langkah yang harus dikerjakan.

\section{2) Penarikan Kesimpulan}

Berikut indikator berpikir logis penarikan kesimpulan yang meliputi melakukan pengecekan kembali dari beberapa teknik yang digunakan.

a) Teknik Tes

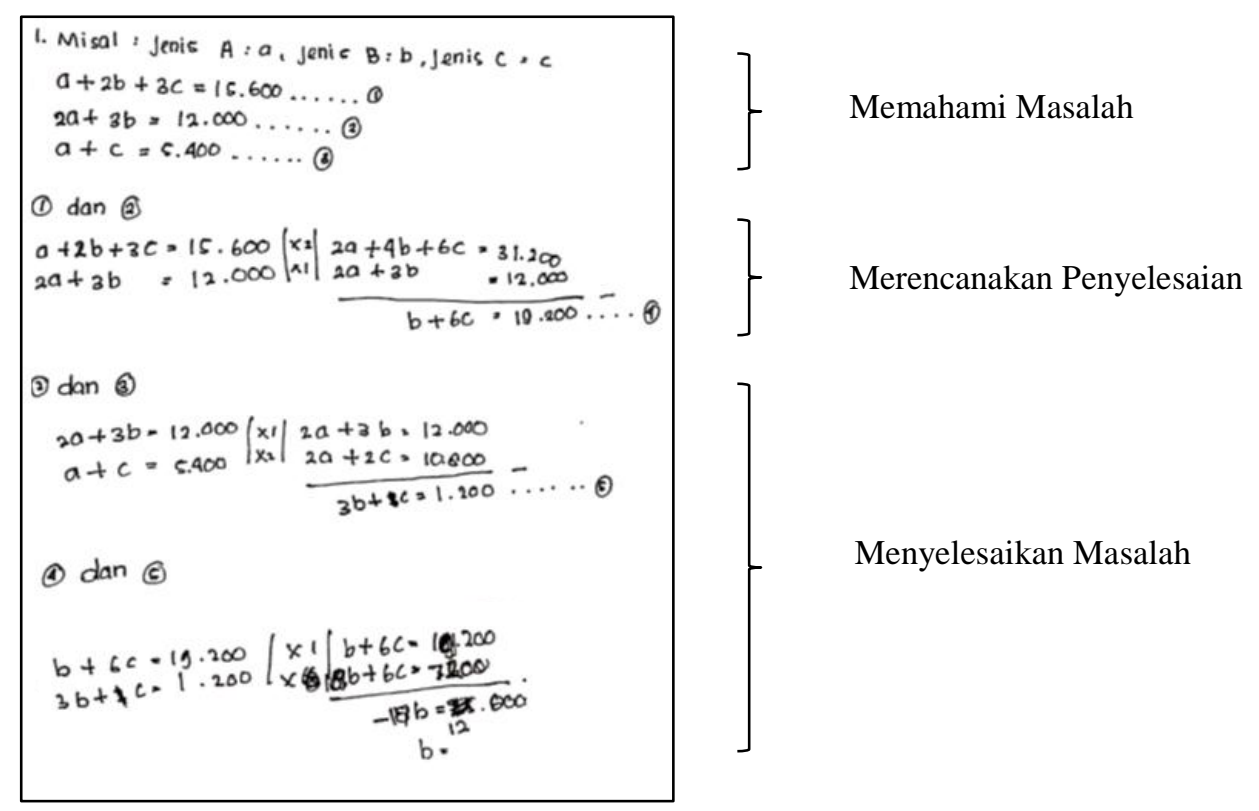

Gambar 6. Jawaban SI Soal Nomor Satu Penarikan Kesimpulan

Diketahui didalam hasil jawaban yang dikerjakan siswa, siswa SI tidak melakukan tahapan melakukan pengecekan kembali. Dia merasa kebingungan dalam menyelesaikan masalah yang diberikan, sekaligus tidak dapat menyelesaikan sampai

Alifmatika: Jurnal Pendidikan dan Pembelajaran Matematika, Desember 2020, Vol. 2, No. 2 
akhir. Oleh karenanya, dapat diketahui pula bahwa siswa SI tidak melakukan tahapan pengecekan kembali di lembar jawaban siswa.

b) Teknik Wawancara

P05 : Apakah ada kendala dalam pengerjaan soal nan?

SI05 : Kendalanya saya itu waktu meamsukan angka ke persamaan 4, 5 dan persamaan 2, 3 jadi salah. Akhirnya salah hasilnya

P06 : Kamu sudah mengerjakan, kamu yakin nggak sama jawabanmu?

SI06 : Tidak yakin karena persamaan 2, 3 tadi salah. Jadi kalau awal saja salah maka kebawah juga salah.

Berdasarkan hasil wawancara yang dilakukan, diketahui bahwa siswa SI menyadari bahwa dia melakukan kesalahan, ketika memasukkan angka ke persamaan empat dan persamaan lima sekaligus persamaan dua dan persamaan tiga. Selain itu, dia juga menyadari bahwa dia juga tidak yakin dalam menyelesaikan permasalahan tersebut, karena menurutnya memasukkan angka ke persamaan dua dan persamaan tiga salah, sehingga ketika awal sudah salah maka ke bawah juga salah. Jadi siswa SI tidak melalui tahapan melakukan pengecekan kembali. Hasil ini sesuai dengan hasil penelitian yang didapat oleh (Tohir, 2017) menunjukan bahwa siswa dengan kemampuan sedang dan rendah seringkali mengabaikan pengecekan kambali terhadap hasil pekerjaan yang telah didapat.

c) Teknik Observasi

Pada pengamatan yang dilakukan peneilti siswa SI ketika waktu sudah habis dia langsung mengumpulkan hasil kerjanya kepada peneliti, tanpa melakukan pengoreksian kembali. karena waktu sudah dinyatakan habis, dan dia merasa tidak bisa membenarkan kembali jawabannya maka selesai atau tidak, tetap harus dikumpulkan.

Pada soal nomor dua terlihat pada gambar 5. siswa SI tidak menuliskan hasil jawabannya.

\section{Kemampuan Berpikir Logis Siswa pada Subjek SC yang Memiliki Kecerdasan Interpersonal Aspek Social Communication dalam Menyelesaikan Masalah Matematika Realistik Materi SPLTV}

Siswa pada subjek SC yang memiliki kecerdasan interpersonal aspek social communication adalah erat kaitannya dengan kemampuan individu yang meliputi kemampuan berkomunikasi dengan santun dan kemampuan mendengarkan efektif. Berikut hasil penyelesaian siswa SC yang memiliki kecerdasan interpersonal aspek social communication pada nomor satu.

1) Keruntutan Berpikir

Pada indikator logis keruntutan berpikir yang meliputi memahami masalah dan merencanakan penyelesaian. Berikut adalah hasil dari beberapa teknik pada soal nomor satu.

a) Teknik Tes

Berikut adalah hasil penyelesaian siswa SC yang memiliki kecerdasan interpersonal aspek social communication.

Alifmatika: Jurnal Pendidikan dan Pembelajaran Matematika, Desember 2020, Vol. 2, No. 2 


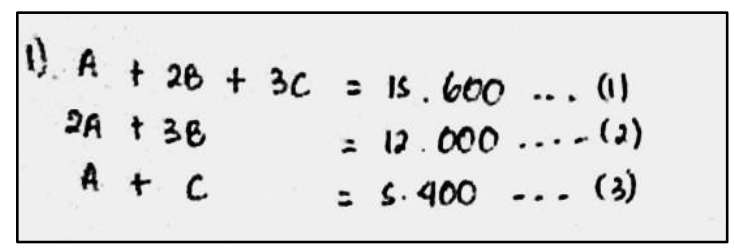

Gambar 7. Jawaban SC Soal Nomor Satu Keruntutan Berpikir

Dari hasil penyelesaian yang dilakukan oleh siswa SC diketahui bahwa siswa yang memiliki kecerdasan interpersonal aspek social communication pada tahap memahami masalah, siswa SC dapat memahami informasi yang ada pada soal. Dia memhami informasi (diketahui dan ditanyakan) secara tersirat.

b) Teknik Wawancara

Berikut adalah hasil wawancara yang diperoleh dari siswa SC.

P01 : Kamu paham nggak dengan soal tadi?

SC01 : Paham

P02 : Jika kamu paham, informasi apa yang kamu dapatkan dari soal tersebut?

SC02: Tadi itu, saya yang nomor 1 mencari harga yang paling mahal, kalau yang ke dua tentang umur, menentukan umur dua orang dijumlah, jumlah umurnya dua orang

P03 : Menurut kamu setelah membaca soal diatas, apa yang diketahui dan apa yang ditanyakan?

SC03: Yang nomor 1 itu kalau misalkan beli barang tapi kan belum tau satuanya berapa, jadi dari soal itu bisa tau harga satuanya. Satu benda itu berapa harganya gitu maksudnya, terus cari yang paling mahal. Kalau yang nomor 2 ini yang ditanyakan jumlah umurnya Dira sama Erik, sedangkan yang diketahui itu umurnya masih belum tau, kayak Dira ini umurnya lebih tua daripada Erik.

Pada hasil wawancara yang diperoleh diketahui bahwa siswa SC paham dengan informasi yang terdapat didalam soal. Untuk membuat pemodelan harus paham terlebih dengan informasi apa yang ada pada soal dengan memisalkan agar lebih mudah untuk dikerjakan. Dia menyebutkan untuk yang ditanyakan adalah harga jenis campuran kedelai manakah yang lebih mahal. Selain itu dia menyebutkan bahwa jika kita membeli barang tapi tidak dapat menentukan harga satuan terlebih dahulu dan dari soal yang diberikan bisa tau harga satuannya. Terlihat bahwa siswa SC sangat paham dengan informasi yang didapatkan dari soal. Menurut hasil penelitian Wulantina (Tohir, 2019) menyimpulkan bahwa siswa dengan kemampuan tinggi pada tahap persiapan siswa mengidentifikasi masalah yang ditanyakan dengan baik, siswa memilih informasi yang dibutuhkan dan informasi yang tidak dibutuhkan dalam penyelesaian masalah dengan tepat.

c) Teknik Observasi

Pada hasil pengamatan yang dilakukan oleh peneliti, terlihat ketika siswa SC melakukan tahapan memahami masalah dengan sangat yakin dan terlihat sangat serius ketika mengerjakan soal yang diberikan.

Siswa SC dapat memenuhi tahapan memahami masalah dalam indikator penyelesaian masalah berdasarkan langkah Polya. Kemudian pada tahap merencanakan masalah siswa SC berhasil untuk mengerjakannya. Jadi dapat disimpulkan bahwa siswa

Alifmatika: Jurnal Pendidikan dan Pembelajaran Matematika, Desember 2020, Vol. 2, No. 2 
SC pada indikator berpikir logis tahapan memahami masalah dan merencanakan masalah dapat melewatinya.

2) Kemampuan Berargumen

Pada indikator logis keruntutan berpikir yang meliputi menyelesaikan masalah.

a) Teknik Tes

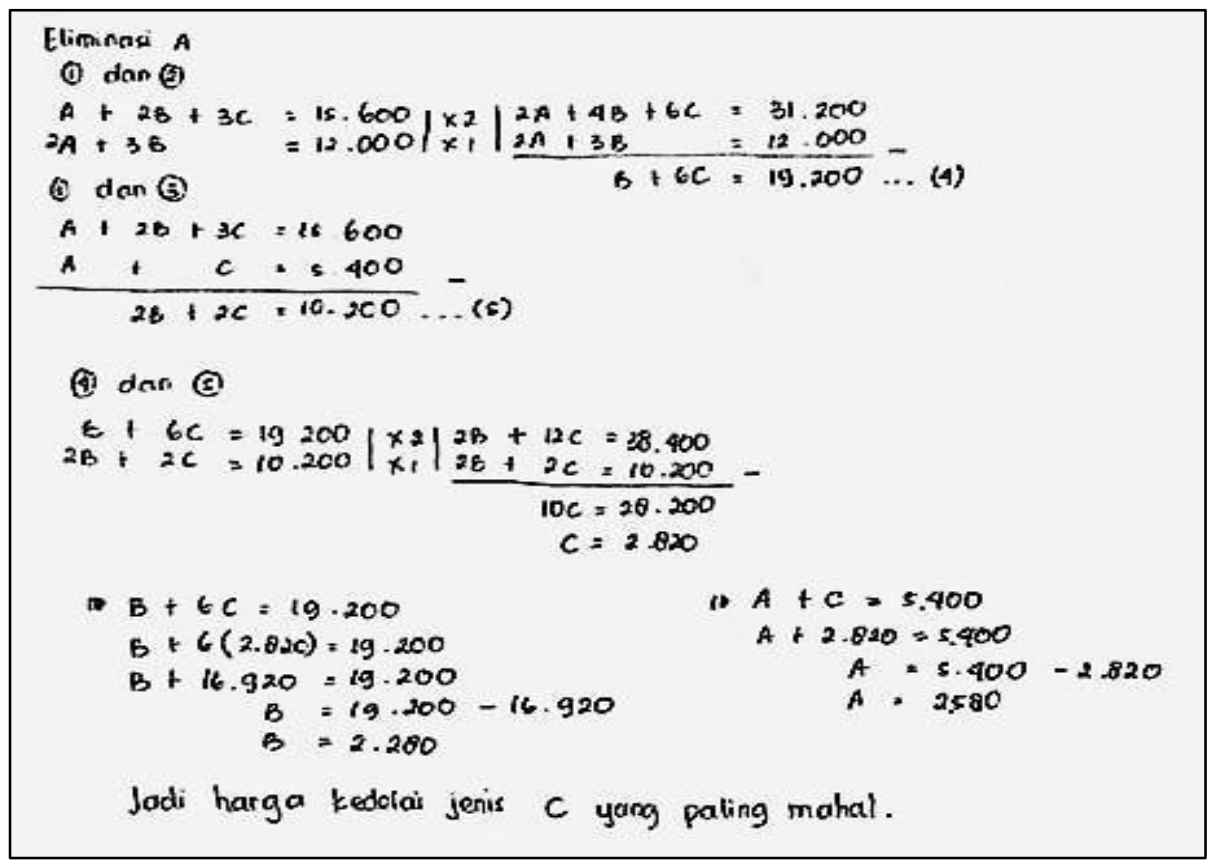

Gambar 8. Jawaban SC Soal Nomor Satu Kemampuan Berargumen

Berdasarkan hasil jawaban yang didapatkan diperoleh bahwa siswa SC sangat mudah sekali untuk menyelesaikan masalah yang diberikan. Terlihat bahwa siswa SC menggunakan metode gabungan (eliminasi dan substitusi). Melakukan eliminasi persamaan satu dan persamaan dua untuk menghasilkan persamaan yang baru yaitu persamaan empat, kemudian untuk menghasilkan persmaan lima menggunakan persamaan satu dan persamaan tiga.

Setelah mendapatkan persamaan baru empat dan lima selanjtnya dia melakukan eliminasi terhadap keduanya dan menemukan salah satu nilai yang dicari yakni harga dari $\mathrm{C}=2.820$. Kemudian karena harga $\mathrm{C}$ sudah ada, mensubstitusikan harga $\mathrm{C}$ tersebut ke persamaan empat (yang ada di nilai yang sudah ditemukan dan nilai yang masih abstrak atau belum ditemukan).

b) Teknik Wawancara

Berikut hasil wawancara yang dilakukan kepada siswa SI.

P05 : Terus? Lanngkah-langkah mengerjakan gimana?

SC05: Untuk soal yang pertama, pertama itu membaca keseluruhan soal. Setelah membaca soal hal-hal yang diketahui itu dimisalkan. Setelah dimisalkan dibuat persamaan, kemudian setelah itu dikerjakan pake cara biasanya pake campuran, eliminasi dulu baru disubstitusikan. Kalau yang nomor 2 itu sama, baca soal secara keseluruhan setelah itu dimisalkan, yang nomor 2 kan nyari umur, jadi yang nomor 2 itu harus lebih teliti lagi.setelah itu buat persamaan juga kayak

Alifmatika: Jurnal Pendidikan dan Pembelajaran Matematika, Desember 2020, Vol. 2, No. 2 
nomor $1 \mathrm{itu}$. Lalu, dikerjakan sama, kayak nomor satu pake campuran eliminasi kemudian di substitusikan.

Dari hasil peroleh wawancara, siswa SC terlihat sangat paham dengan apa yang harus dilakukan dengan menyelesaikan masalah menggunakan metode gabungan (eliminasi dan substitusi). Dia menyebutkan langkah yang pertama dilakukan adalah membaca soal secara keseluruhan, kemudian memisalkan apa yang diketahui. Setelah memisalkan dan membuat persamaan, maka dikerjakan menggunakan metode campuran dieleminasi dulu baru disubstitusikan.

c) Teknik Observasi

Dari hasil pengamatan yang dilakukan secara langsung kepada siswa SC. Siswa SC terlihat sangat luwes sekali dalam menyelesaikan masalah yang diberikan. Selain itu, siswa SC terlihat tidak sama sekali ada kebingungan sedikit pun seperti temantemannya yang lain ketika mengerjakan.

Disimpulkan bahwa siswa SC pada indikator berpikir logis kemampuan berargumen pada tahapan menyelesaikan masalah dapat dilewatinya dengan baik.

3) Penarikan Kesimpulan

Pada indikator berpikir logis penarikan kesimpulan meliputi tahapan melakukan pengecekan kembali. berikut hasil yang diperoleh.

a) Teknik Tes

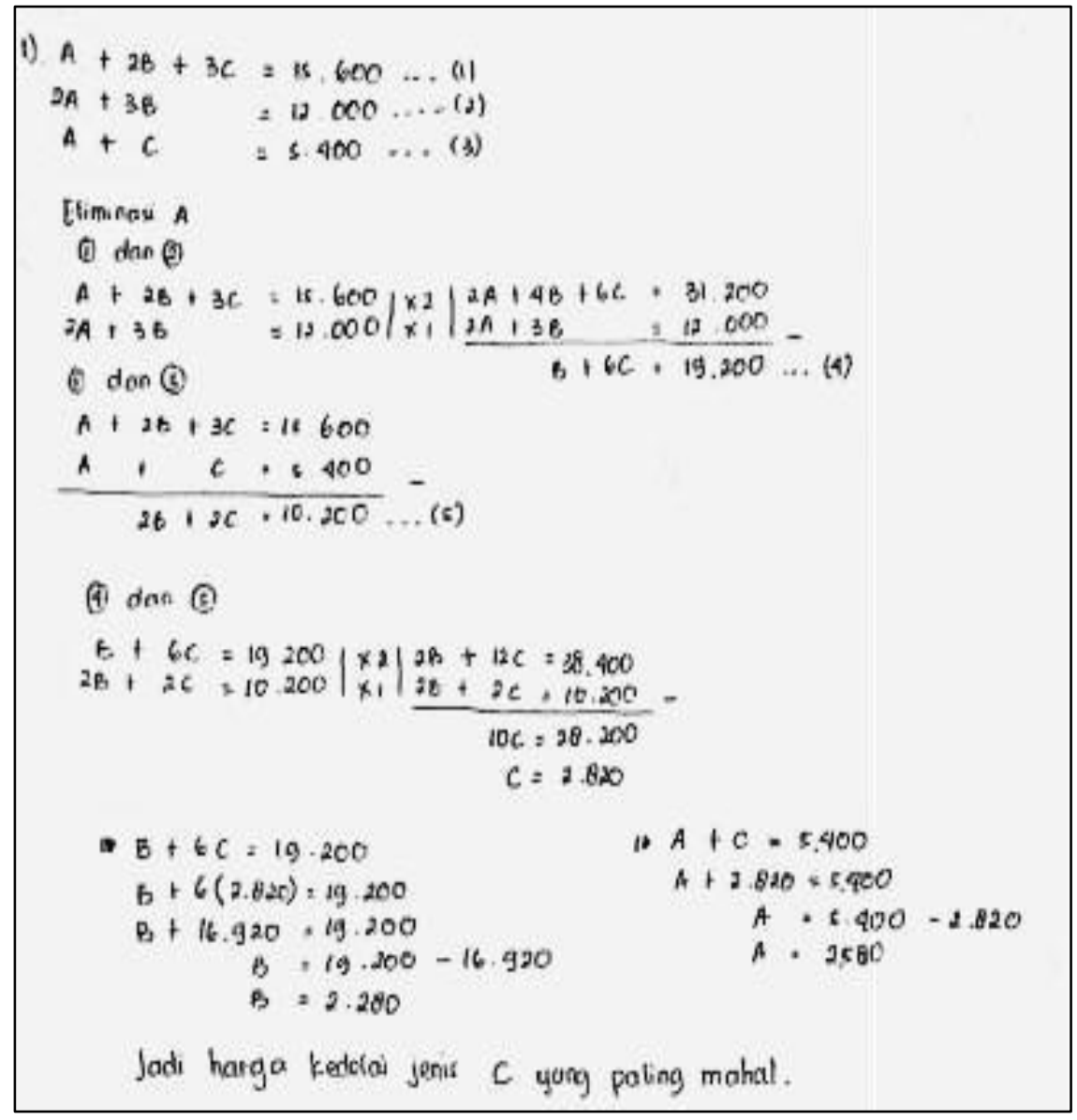

Gambar 9. Jawaban SC Soal Nomor Satu Penarikan Kesimpulan

Alifmatika: Jurnal Pendidikan dan Pembelajaran Matematika, Desember 2020, Vol. 2, No. 2 
Untuk tahapan pengecekan kembali terlihat bahwa siswa SC tidak melakukan tahapan tersebut. dia tidak menuliskan ketika sudah mendapatkan masing-masing harga dari jenis campuran kedelai $\mathrm{A}, \mathrm{B}$ dan $\mathrm{C}$ dia tidak mengecek kembali hasil jawaban dengan menstubstitusikan ke persamaan yang ada. Sehingga tidak tahu apakah jawaban yang didapat sudah dapat dipastikan kebenarannya atau malah sebaliknya.

b) Teknik Wawancara

Berikut hasil wawancara yang diperoleh.

P06 : Kan barusan sudah dikerjakan, menurut kamu jawabanmu ini benar apa enggak? SC06: Benar bu

P07 : Kok bisa bilang sudah benar, apa sudah yakin? Jawabannya di masukkan ke persamaan ini benar, ke persamaan ini benar, apakah sudah di cek kebenarannya?

SC07 : Biasanya di cek dulu tapi tadi keburu ditunggu teman-teman, $\mathrm{Bu}$

Pada teknik ini terlihat bahwa siswa SC sangat paham sekali dan yakin dengan cara yang digunakan untuk menyelesaikan masalah yang diberikan, sehingga menemukan jawaban yang diharapkan. Dia menyebutkan bahwa jawaban yang didapatkan sudah yakin benar. Dia juga mengatakan untuk tahapan pengecekan kembali biasanya dilakukan, namun karena dia terburu-buru untuk menjumpai teman-temannya maka dia tidak melakukan tahapan tersebut.

\section{c) Teknik Observasi}

Pada teknik observasi atau pengamatan, terlihat secara langsung bahwa siswa SC terlihat sangat mudah sekali dalam mengerjakan soal, dia yakin dan terlihat santai namun pasti ketika menyelesaikan masalah yang diberikan. Ketika peneliti melihat di lembar jawabannya, tulisan siswa SC sangat rapi dan terlihat dia mengerjakan secara runtut seperti dia sudah terbiasa ketika mengerjakan model soat tersebut.

Disimpulkan bahwa siswa SC dapat memenuhi indikator dari berpikir logis yaitu melakukan penarikan kesimpulan dan juga dapat melakukan pengecekan kembali pada indikator penyelesaian masalah berdasarkan langkah Polya namun tidak dituliskan pada lembar jawaban karena sudah yakin bahwa jawaban sudah benar.

Berikut hasil penyelesaian siswa SC yang memiliki kecerdasan interpersonal aspek social communication pada nomor dua.

\section{1) Keruntutan Berpikir}

Pada indikator logis keruntutan berpikir yang meliputi memahami masalah dan merencanakan penyelesaian. Berikut adalah hasil dari beberapa teknik pada soal nomor dua.

a) Teknik Tes

Berikut adalah hasil penyelesaian siswa SC yang memiliki kecerdasan interpersonal aspek social communication. 


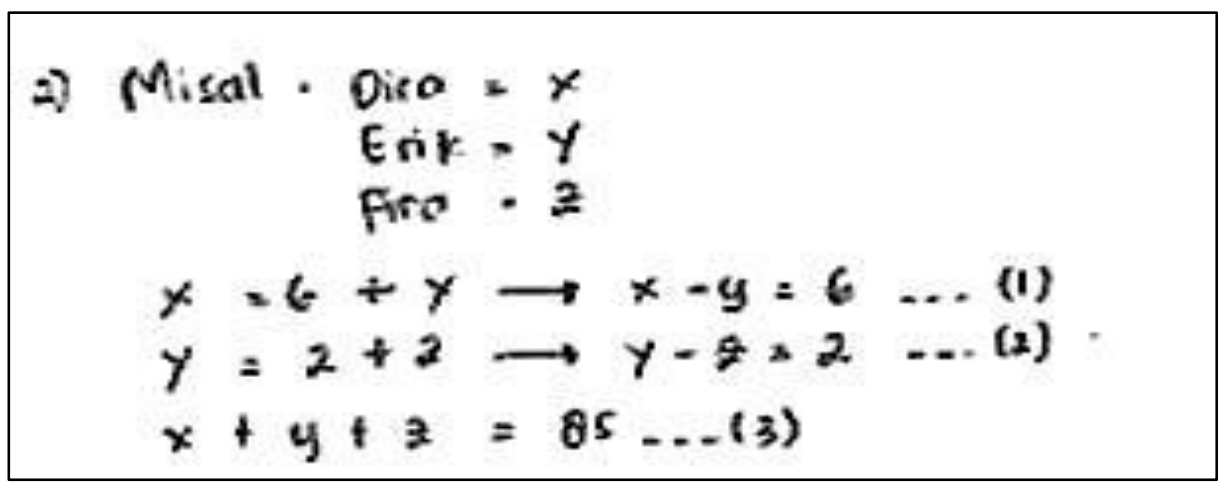

Gambar 10. Jawaban SC Soal Nomor Dua Keruntutan Berpikir

Dari hasil penyelesaian yang dilakukan oleh siswa SC diketahui bahwa siswa yang memiliki kecerdasan interpersonal aspek social communication pada tahap memahami masalah, siswa SC dapat memahami informasi yang ada pada soal. Dia memahami informasi (diketahui dan ditanyakan) secara tersirat. Terlihat didalam soal siswa SC membuat pemisalan dengan Dira dimisalkan dengan $\mathrm{x}$, Erik dimisalkan dengan y dan Fira dimisalkan dengan z. Dia membuat pemodelan bahwa diketahui didalam soal Dira berumur 6 tahun lebih tua dari Erik. Kemudian dia membuat pemodelan matematika $x=6+y$. Sedangkan umur Erik 2 tahun lebih tua dari Fira. Dia membuat pemodelan $y=2+z$. Jika jumlah umur Dira, Erik dan Fira adalah 85 tahun, pemodelan matematikanya adalah $x+y+z=85$.

b) Teknik Wawancara

Berikut adalah hasil wawancara yang diperoleh dari siswa SC.

P01 : Kamu paham nggak dengan soal tadi?

SC01: Paham

P02 : Jika kamu paham, informasi apa yang kamu dapatkan dari soal tersebut?"

SC02: Tadi itu, saya yang nomor 1 mencari harga yang paling mahal, kalau yang ke dua tentang umur, menentukan umur dua orang dijumlah, jumlah umurnya dua orang

P03 : Menurut kamu setelah membaca soal diatas, apa yang diketahui dan apa yang ditanyakan?

SC03: Yang nomor 1 itu kalau misalkan beli barang tapi kan belum tau satuanya berapa, jadi dari soal itu bisa tau harga satuanya. Satu benda itu berapa harganya gitu maksudnya, terus cari yang paling mahal. Kalau yang nomor 2 ini yang ditanyakan jumlah umurnya Dira sama Erik, sedangkan yang diketahui itu umurnya masih belum tau, kayak Dira ini umurnya lebih tua daripada Erik.

Pada hasil wawancara yang diperoleh diketahui bahwa siswa SC paham dengan informasi yang terdapat didalam soal. Untuk membuat pemodelan harus paham terlebih dengan informasi apa yang ada pada soal dengan memisalkan agar lebih mudah untuk dikerjakan. Dia menyebutkan untuk yang nomor dua sama, jadi baca dulu soalnya secara keseluruhan setelah itu dimisalkan, yang nomor dua mencari umurjadi yang nomor dua itu harus lebh teliti. Setelah itu buat persamaan juga kayak nomor 1 itu. Lalu, dikerjakan sama, kayak nomor satu pake campuran eliminasi kemudian di substitusikan.

Alifmatika: Jurnal Pendidikan dan Pembelajaran Matematika, Desember 2020, Vol. 2, No. 2 
c) Teknik Observasi

Pada hasil pengamatan yang dilakukan oleh peneliti, terlihat ketika siswa SC melakukan tahapan memahami masalah dengan sangat yakin dan terlihat sangat serius ketika mengerjakan soal yang diberikan.

2) Kemampuan Berargumen

Pada indikator logis keruntutan berpikir yang meliputi memahami masalah dan merencanakan penyelesaian.

a) Teknik Tes

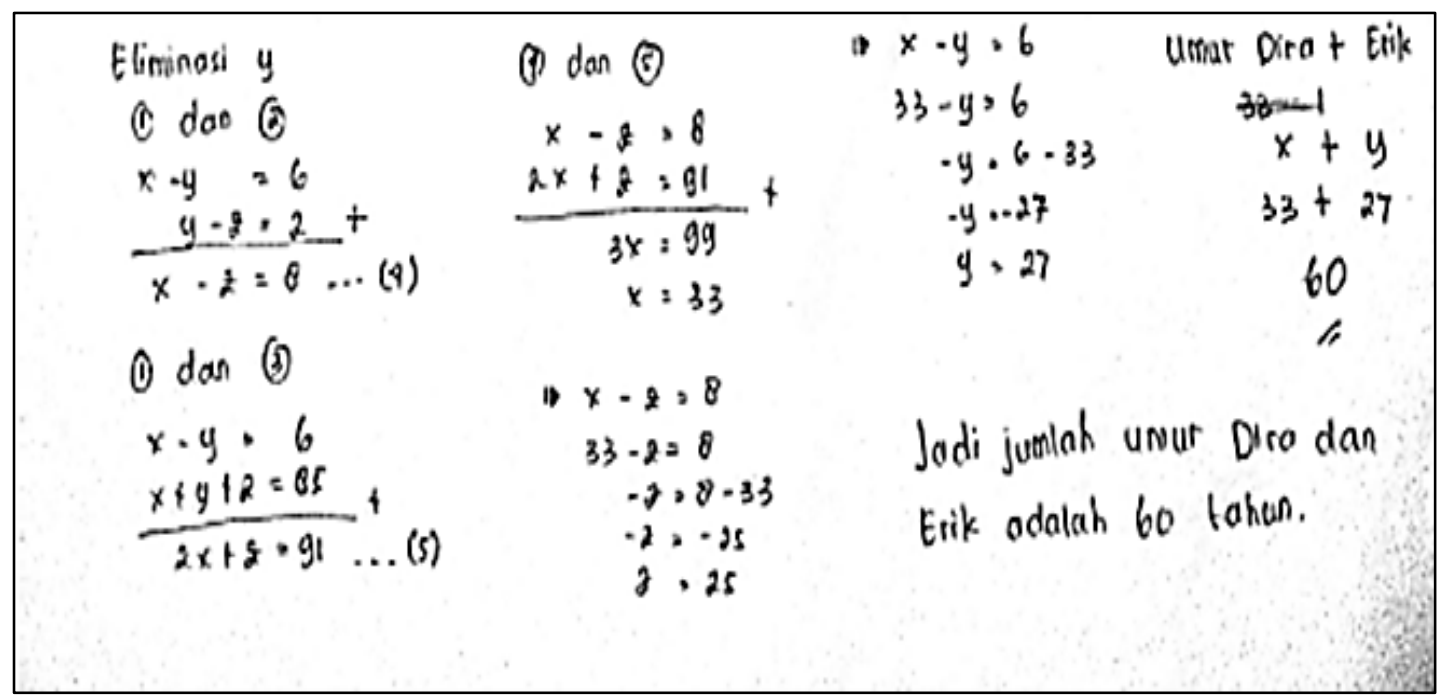

Gambar 11. Jawaban SC Soal Nomor Dua Kemampuan Berargumen

Pada hasil jawaban yang didapatkan diperoleh bahwa siswa SC sangat mudah sekali untuk menyelesaikan masalah yang diberikan. Terlihat bahwa siswa SC menggunakan metode gabungan (eliminasi dan substitusi).

b) Teknik Wawancara

Berikut hasil wawancara yang dilakukan kepada siswa SI.

P05 : Terus? Langkah-langkah mengerjakan gimana?

SC05: Untuk soal yang pertama, pertama itu membaca keseluruhan soal. Setelah membaca soal hal-hal yang diketahui itu dimisalkan. Setelah dimisalkan dibuat persamaan, kemudian setelah itu dikerjakan pake cara biasanya pake campuran, eliminasi dulu baru disubstitusikan. Kalau yang nomor 2 itu sama, baca soal secara keseluruhan setelah itu dimisalkan, yang nomor 2 kan nyari umur, jadi yang nomor 2 itu harus lebih teliti lagi.setelah itu buat persamaan juga kayak nomor 1 itu. Lalu, dikerjakan sama, kayak nomor satu pake campuran eliminasi kemudian di substitusikan.

Berdasarkan hasil peroleh wawancara, siswa SC terlihat sangat paham dengan apa yang harus dilakukan dengan menyelesaikan masalah menggunakan metode gabungan (eliminasi dan substitusi). Dia menyebutkan langkah yang pertama dilakukan adalah membaca soal secara keseluruhan, kemudian memisalkan apa yang diketahui. Unutk nomor dua mencari umur, jadi yang nomor dua harus lebih teliti lagi. Setelah

Alifmatika: Jurnal Pendidikan dan Pembelajaran Matematika, Desember 2020, Vol. 2, No. 2 
memisalkan dan membuat persamaan, maka dikerjakan menggunakan metode campuran dieleminasi dulu baru disubstitusikan.

c) Teknik Observasi

Dari hasil pengamatan yang dilakukan secara langsung kepada siswa SC. Siswa SC terlihat sangat luwes sekali dalam menyelesaikan masalah yang diberikan. Selain itu, siswa SC terlihat tidak sama sekali ada kebingungan sedikit pun seperti temantemannya yang lain ketika mengerjakan.

3) Penarikan Kesimpulan

Pada indikator berpikir logis penarikan kesimpulan meliputi tahapan melakukan pengecekan kembali. Berikut hasil yang diperoleh.

a) Teknik Tes

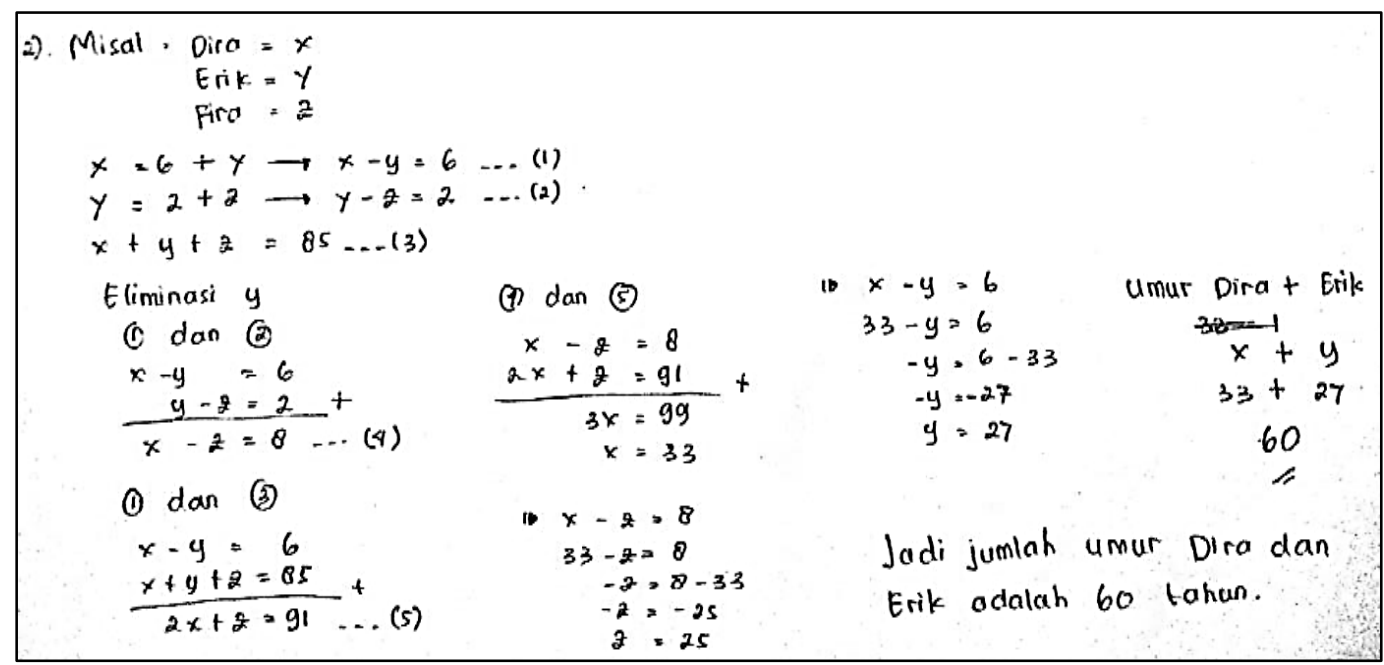

Gambar 12. Jawaban SC Soal Nomor Dua Penarikan Kesimpulan

Untuk tahapan pengecekan kembali terlihat bahwa siswa SC tidak melakukan tahapan tersebut. dia tidak menuliskan ketika sudah mendapatkan masing-masing nilai $x, y$ dan $z$ dia tidak mengecek kembali hasil jawaban dengan menstubstitusikan ke persamaan yang ada. Sehingga tidak tahu apakah jawaban yang didapat sudah dapat dipastikan kebenarannya atau malah sebaliknya.

b) Teknik Wawancara

Berikut hasil wawancara yang diperoleh.

P06 : Kan barusan sudah dikerjakan, menurut kamu jawabanmu ini benar apa enggak?

SC06: Benar, $\mathrm{Bu}$

P07 : Kok bisa bilang sudah benar, apa sudah yakin? Jawabannya di masukkan ke persamaan ini benar, ke persamaan ini benar, apakah sudah di cek kebenarannya?

SC07: Biasanya di cek dulu tapi tadi keburu ditunggu teman-teman, Bu.

Pada teknik ini terlihat bahwa siswa SC sangat paham sekali dan yakin dengan cara yang digunakan untuk menyelesaikan masalah yang diberikan, sehingga

Alifmatika: Jurnal Pendidikan dan Pembelajaran Matematika, Desember 2020, Vol. 2, No. 2 
menemukan jawaban yang diharapkan. Dia menyebutkan bahwa jawaban yang didapatkan sudah yakin benar. Dia juga mengatakan untuk tahapan pengecekan kembali biasanya dilakukan, namun karena dia terburu-buru untuk menjumpai teman-temannya maka dia tidak melakukan tahapan tersebut.

\section{c) Teknik Observasi}

Pada teknik observasi atau pengamatan, terlihat secara langsung bahwa siswa SC terlihat sangat mudah sekali dalam mengerjakan soal, dia yakin dan terlihat santai namun pasti ketika menyelesaikan masalah yang diberikan. Ketika peneliti melihat di lembar jawabannya, tulisan siswa SC sangat rapi dan terlihat dia mengerjakan secara runtut seperti dia sudah terbiasa ketika mengerjakan model soal tersebut.

Dengan demikian, berpikir logis siswa dalam menyelesaikan masalalah matematika realistik perlu selalu diasah dan dikembangkan agar kecedasan interpersonal siswa meningkat juga. Dalam hal ini, matematika sangat penting dan berperan aktif dalam membantu siswa terhadap logika berpikirnya. Bahkan dapat dikatakan bahwa matematika adalah ibu atau ibu dari berbagai ilmu yang dipelajari oleh manusia. Hal ini sesuai dengan pendapat Carl Friedrich Gauss (Narlikar, 2013) yang mengatakan bahwa matematika adalah ratu sains. Menurut Thalhah, Tohir, Nguyen, Shankar, \& Rahim (2019) mengatakan bahwa matematika adalah fondasi dari setiap tatanan sains kontemporer. Matematika juga memegang peranan penting dalam memajukan Negara Indonesia dan untuk kesejahteraan bangsa Indonesia melalui pengembangan Ilmu Pengetahuan dan Teknologi (IPTEK) yang tidak lepas dari ilmu dasar yaitu matematika. Matematika adalah disiplin ilmu untuk mempelajari ilmu-ilmu lain. Matematika merupakan mata pelajaran yang penting untuk dipelajari, sehingga yang terjadi adalah matematika merupakan mata pelajaran yang menyenangkan bagi siswa, sehingga nantinya siswa akan tertarik, dan gemar belajar matematika dan pada akhirnya nilai yang diperoleh siswa sangat tinggi. memuaskan. dan siswa dapat menerapkan matematika yang telah mereka pelajari dalam kehidupan sehari-hari. Dengan demikian ilmu matematika yang dimiliki tampaknya dapat bermanfaat bagi dirinya dan orang lain. Hal ini karena kemampuan berpikir dalam mengidentifikasi dan mengonstruksi rumus matematika sangat dibutuhkan untuk menumbuhkan pemahaman siswa terhadap materi dan menghasilkan pembelajaran yang bermakna (Tohir, Abidin, Dafik, \& Hobri, 2018).

\section{KESIMPULAN DAN SARAN}

Berdasarkan hasil dan pembahasan diatas, didapatkan kesimpulan dan saran sebagai yaitu siswa yang memiliki kecerdasan interpersonal aspek social sensitivity memenuhi satu indikator berpikir logis keruntutan berpikir dan memenuhi dua indikator penyelesaian masalah namun masih kurang. Siswa memiliki kecerdasan interpersonal aspek social insight dapat memenuhi dua indikator berpikir logis keruntutan berpikir dan kemampuan berargumen. Selain itu, dapat memenuhi tiga indikator penyelesaian masalah namun masih kurang. Sedangkan siswa yang memiliki kecerdasan interpersonal aspek social communication memenuhi semua indikator berpikir logis keruntutan berpikir, kemampuan berargumen dan penarikan kesimpulan. Selain itu, dapat memenuhi semua indikator penyelesaian masalah. Sedangkkan dalam mengembangkan kemampuan siswa, guru haru lebih sering memberikan masalahmasalah yang berhubungan dengan masalah yang dekat dengan kehidupan sehari-hari.

Alifmatika: Jurnal Pendidikan dan Pembelajaran Matematika, Desember 2020, Vol. 2, No. 2 


\section{DAFTAR PUSTAKA}

Andriawan, B. (2014). Identifikasi Kemampuan Berpikir Logis dalam Pemecahan Masalah Matematika Pada Siswa Kelas VIII-1 SMP Negeri 2 Sidoarjo. MATHEdunesa, 3(2), 42-48.

Aprilia, F. (2013). Hubungan Antara Kecerdasan Interpersonal dengan Perilaku Kenakalan Remaja. Skripsi. Semarang: Universitas Negeri Semarang.

Cahyani, H., \& Setyawati, R. W. (2017). Pentingnya Peningkatan Kemampuan Pemecahan Masalah Melalui PBL untuk Mempersiapkan Generasi Unggul Menghadapi MEA. PRISMA, Prosiding Seminar Nasional Matematika, 151-160.

Erviana, T. (2019). Kemampuan Penalaran Matematis Siswa dalam Memecahkan Masalah Aljabar Berdasarkan Gaya Kognitif Field Independent. Alifmatika: Jurnal Pendidikan Dan Pembelajaran Matematika, 1(1), 61-73.

Huberman, A. M., Miles, M., \& Saldana, J. (2014). Qualitative data analysis: A methods sourcebook. The United States of America: SAGE Publications. Höök, P.(2001). Stridspiloter $i$ Vida Kjolar-Om Ledarutveckling Och Jämställdhet.

Kemendikbud. (2003). UU Nomor 20 Tahun 2003 tentang Sistem Pendidikan Nasional. Jakarta: Kementerian Pendidikan dan Kebudayaan.

Latif, M. (2016). Orientasi ke Arah Pemahaman Filsafat Ilmu. Jakarta: Prenadamedia Group.

Mukhlis, M., \& Tohir, M. (2019). Instrumen Pengukur Creativity and Innovation Skills Siswa Sekolah Menengah di Era Revolusi Industri 4.0. Indonesian Journal of Mathematics and Natural Science Education, 1(1), 65-73. https://doi.org/10.5281/zenodo.3723452

Munawwarah, M., Laili, N., \& Tohir, M. (2020). Keterampilan Berpikir Kritis Mahasiswa dalam Memecahkan Masalah Matematika Berdasarkan Keterampilan Abad 21. Alifmatika: Jurnal Pendidikan Dan Pembelajaran Matematika, 2(1), 3758. https://doi.org/10.35316/alifmatika.2020.v2i1.37-58

Narlikar, J. V. (2013). Mathematics: The Queen of Sciences. India: Inter-University Cencer for Astronomy and Astrophysics.

Polya, G. (1973). How to Solve it Second Edition (2nd ed.). New York, NY: Princeton University Press.

Sholeh, K. (2016). Kecerdasan Majemuk Berorientasi pada Partisipasi Peserta Didik. Yogyakarta: Pustaka Pelajar.

Thalhah, S. Z., Tohir, M., Nguyen, P. T., Shankar, K., \& Rahim, R. (2019). Mathematical Issues in Data Science and Applications for Health care. International Journal of Recent Technology and Engineering, 8(2S11), 41534156. https://doi.org/10.35940/ijrte.B1599.0982S1119

Tohir, M. (2017). Pengembangan Bahan Ajar Olimpiade Matematika Berdasarkan Model Pemecahan Masalah untuk Meningkatkan Kemampuan Penalaran Matematis Siswa. In Tesis. Magister Pendidikan Matematika Universitas Jember. https://doi.org/10.13140/RG.2.2.31121.79200 
Tohir, M. (2019). Keterampilan Berpikir Kreatif Siswa dalam Menyelesaikan Soal Olimpiade Matematika Berdasarkan Level Metakognisi. Alifmatika: Jurnal Pendidikan dan Pembelajaran Matematika, 1(1), 1-14. https://doi.org/10.35316/alifmatika.2019.v1i1.1-14

Tohir, M., Abidin, Z., Dafik, D., \& Hobri, H. (2018). Students Creative Thinking Skills in Solving Two Dimensional Arithmetic Series Through Research-Based Learning. Journal of Physics: Conference Series, 1008(1), 012072. https://doi.org/10.1088/1742-6596/1008/1/012072

Tohir, M., Maswar, M., Atikurrahman, M., Saiful, S., \& Pradita, D. A. R. (2020). Prospective Teachers' Expectations of Students' Mathematical Thinking Processes in Solving Problems. European Journal of Educational Research, 9(4), 17351748. https://doi.org/10.12973/eu-jer.9.4.1735

Tohir, M., Susanto, Hobri, Suharto, \& Dafik. (2018). Students' Creative Thinking Skills in Solving Mathematics Olympiad Problems Based on Problem-Solving Polya and Krulik-Rudnick Model. Advanced Science Letters, 24(11), 8361-8364. https://doi.org/10.1166/asl.2018.12563 